\title{
Islamic Ideal and Political Reality in Late-Classical Muslim Thought
}

\section{by Farhang Rajaee}

Like all great religions, Islam perceives God as the raison d'etre of all things. ${ }^{1}$ Moreover, as a comprehensive scheme, Islam seeks to mold every sphere of man's life in accordance with the moral principles it propagates. The end of Islamic political thought thus is to materialize these principles. Because they are codified in a body of law, the Islamic polity may be referred to as a nomocracy, making Islamic political thought a legal enterprise. Moreover, unlike the Western tradition of political thought in which the discussion of the nature of the "state" plays a central role, the "state" as an artificial corporate entity distinct from the community does not exist in Islamic political thought, but the "state" in the sense of a system of governance is a given. The primary question for any Islamic political thinker does not pertain to the nature of the state, but rather to the leadership of the community, on the one hand, and the relationship of that community with other political communities on the other. The political history of Islam has witnessed a host of various ways by which the aforementioned concerns have been dealt with. Up to modern times and the emergence of a new breed of thinkers responding to the Western impact, who deserve a category of their own, Islamic political thought could be discerned from the works of the following four groups: the theologian jurisconsults (fuqaha), the literalists or the authors of the mirrors of the princes (udaba), the historian/philosophers (mu'arikhin), and the philosophers (falasifa). ${ }^{2}$

Farhang Rajaee is a member of the Faculty of Law and Political Science at the University of Tehran where he teaches International Relations and Islamic Political Thought.

${ }^{1}$ An outline version of this article was presented at the 18th Annual Meeting of the Middle East Studies Association of North America in San Francisco, California, during November 28 through December 1, 1984.

${ }^{2}$ Ann Lambton has a similar categorization, but he does not include the historian/philosopher group. See Ann K.S. Lambton, State and Government in Medieval Islam (New York: Oxford University Press, 1981), p. xvi. I should acknowledge my appreciation to Professor S. Hossein Nasr for bringing the historian/philosopher trend to my attention. Unfortunately very little work has been done on this important body of literature. 
The last group skillfully studied Greek philosophical tradition and civilization and interpreted Islamic thought in terms of the views of political thinkers such as Plato and Aristotle. Such great philosophers as al-Farabi (d. 339/950), Ibn-Sina (Avicenna) (d. 431/1039), and Ibn-Rushd (Averroes) (d. 451/1058) are of this trend. The other group, the historian/philosopher, deal with some of the important questions of politics in their masterpieces on history. The appellation "philosopher of history" cannot be applied to them because they were not trying to find a philosophical explanation of history. They are not historians proper in the sense of being annal writers either. They deal with both philosophy and history in their own special way. Such writers as Muhammad b. Jarrir al-Tabari (d. 310/923), Rashid al-Din Fadl-Allah (d. 718/1318), and Ibn-Khaldun (d. 808/1406) (although many have treated him as one of the philosophers) are in this category. Others took a more direct approach to political issues and concentrated on the practical ways in which the Islamic rulers should exercise their kingship. The authors of the mirrors of the princes, such as, Ibn al-Muqaffa' (d. 142/759), Kayka'us b. Iskandar (d. ca. 479/1086), and Nizam al-Mulk (d. 485/1092) are in this category. The other group, the jurisconsults, are concerned with the law and the way in which the practices of the political rulers should conform to the principles of the Qur'an, the traditions of the Prophet, and other rules promulgated in other sources of Islamic law. Abu Yusuf (d. 128/798), Al-Mawardi (d. 423/1031), Ibn Jama‘a (d. 734/1333), Ibn Taymiyya (d. 729/1328), and Fadl-Allah b. Ruzbihan Khunji (d. 928/1521), the central figure in this article, are among the thinkers of this category. As the custodian of the divine law, this group has had the greatest impact on Islamic political thought and history. They either codified the words or deeds of the leaders of Islam or provided a post eventum justification for the actual rule of the political leaders, but only within the boundaries defined in the law itself in terms of Islamic jurisprudence.

Whereas the philosophers could be accused of heresy for bringing Greek thought and the authors of the mirrors of the princes could also be accused of bringing their respective pre-Islamic traditions, the theologian/jurisconsults were less susceptible to the accusation of unorthodox practices. An additional reason for their success was that they were usually able to strike a balance between the ideal norms and the actual political realities. Each in their own time could vindicate and uphold the divine purpose of the Muslim state and give support to their contemporary rulers in their struggle against sectarian challenges. This legitimizing function of the jurisconsults had its pitfalls. One was that they could withdraw their support and in fact shake the government. It was this ability that made them almost a rival apparatus to the central machinery of governance. The main purpose of this article is to argue that the theologian/jurisconsults consider the best rule to be that which guards against aberrations from the Islamic norms as the jurists interpret them. 


\section{The case of Fadl-Allah illustrates this point.}

When Fadl-Allah b. Ruzbihan was born, the eastern part of the Islamic world was going through a radical change. ${ }^{3}$ The precise date of his birth is not quite known, but the majority of his biographers put it as $860 / 1455$. This coincided with the emergence of Uzun Hassan of the Aq Qoyunlu tribe and his war with Muhammad II of the Ottoman Empire, and with that period in the history of the Safavid Empire which one historian calls "the period of religious government," the period during which Shaykh Junayd (d. 865/1460), Shaykh Heydar (d. 894/1488), and Shaykh Sultan 'Ali (d. 900/1494), respectively, assumed the leadership of the Safavid Sufi order. ${ }^{4}$

Having been born in a family with a strong tendency toward orthodox Sunni belief of the Shafi'i school, Fadll-Allah's education in the sciences of the Qur'an and the Arabic language started very early. By the time he was seventeen he had performed the Hajj pilgrimage. He made a second pilgrimage in $887 / 1482$. While in Hijāz he studied the Minhāj al- 'Abidīn and the Ihyā' Ulüm al-Dīn of al-Ghazali and the Rawdat al-Awarif of Shahab al-Din Suhrawardi. In Medina, he studied the famous Sunni books of traditions, Sahih of al-Bukhāri and the Sahịh of Muslim. Upon his return to his homeland, Fadl-Allah wrote Badì' al-Zamān fi Qișșat Hayy b. Yaqzām.

He set out for a third trip of Hajj, but began his trip by a visit to the court of Abu al-Mozaffar Yaquüb Khan who had then taken over the Aq Qoyunlu Kingdom. The visit was quite normal because Faḍl Allah's uncle Ismāiil Sa‘edi had a high position in the court and he himself had met Prince Maqsud, the son of Uzun Hassan, in Baghdad in 877/1472. ${ }^{5}$ He joined the court and expressed his willingness to write a history of the reign of the King. The result was Tärikh-e 'Alamara-ie Amini, a chronicle of 833-897/1478-91. ${ }^{6}$ It is worth noting that in this work, Fadl-Allah severely attacks the great grandfather of Shah Ismāili. It is no surprise, then, that following the disintegration of the Aq-Qoyunlu Kingdom he had to migrate. He left for Khurasan. Two years after he witnessed the allied forces of Shah Ismail and Babur march into

${ }^{3}$ The biographical data on Fadl-Allah's life is taken from his own scattered references in his own works as well as the following sources: Muhammad Amin Khunji, "Faḍl-Allah b. Ruzbihan Kunju," Farhang-e Iran Zamin, Vol. 4, No. 3 (1335/1956), pp. 273-184; V. Minorsky Persia in A.D. 1478-1491 (London: The Royal Asiatic Society, 1957) vz. the introduction; and Fadl-Allah b. Ruzbihan, Mihman Name-ye Bokhara, ed. Manuchehr Setudeh (Tehran: Tarjomeh va Nashr-e Kitab, 1341/1962), introduction by the editor.

4 See Walter Hinz, Iran's Aufstieg Zum Nationalstaet., translated into Persian by K. Jahandari, 2nd edition (Tehran: Kharazmi, 1361), pp. 15-31 and also sources cited therein.

${ }^{5}$ Ibid., pp. 148-49.

6 This important work has not yet been published in its complete text either in the original Persian or in translation. The late Professor Minorsky published an abridged translation of it many years ago (see note 3 above). 
Khurasan and utterly defeat and kill Abu al-Fath Muhammad Khan Shaybāní, a nephew of the latter, 'Ubayd-Allah, rose against the occupied forces and rescued the kingdom. Before 'Ubayd-Allah set out for the war he vowed that, "if the exalted God granted him victory over this rebellious tribe and if $\mathrm{He}$ helped him in his war with the Babur, during the rest of his life in all matters of the kingdom he would never breach the ordinances of the Islamic law, shariah."7

Following his victory, to fulfill his vow, the young Uz̧bek summoned FaḍlAllah and commissioned him to repare a book on government. The result was a big volume in Persian entitled Sulük al-Malük (The Conduct of Rulers). ${ }^{8}$ The purpose of this political treatise, in the manner of the jurdical trend discussed before, is twofold: to vindicate and uphold the divine purpose of the state and to provide support to the Uzbek Sunni state against the challenge of the Shi'i Safavids. Faḍl-Allah deftly achieved both purposes. His resentment toward the Safavi family, however, on the one hand, and his disagreement with the Shi'i interpretation of leadership, on the other, made his job easier in reaching the second goal. In addition to his portrayal of Shaykh Heydar Safavi as a power hungry leader, he had written a polemical work against the Nahj alHaqq of Allamah Ibn al-Mutahhar al-Hilli in 1503. The rest of this article concentrates on his views on the structure and purpose of an Islamic state.

Fadil-Allah begins his argument by discussing the ideal form of leadership according to the shari'a. He explicates this issue before he indulges in any other discussion. First he defines leadership: ${ }^{9}$

Leadership (Imamate), in the Islamic law (the shariah), is the caliphdom of the prophet in establishing the law and protecting the territory of the nation in the manner in which it will be incumbent upon all people to follow. ${ }^{10}$ (emphases added).

The passage should not be taken to mean that following the Prophet's death the work of the community will be suspended. Leadership is a social necessity (fard kifayah) and as a result a person with the following qualifications should act as the ideal leader. He should be: 1) a member of the tribe of Quraysh, 2) a mujtahid, so that he would know the ordinances of the shariah, 3) a man of independent judgement and managerial talent in order to be able to protect the territory, 4) qualified in financial affairs, 5) brave and daring, so

7 See Fadl-Allah b. Ruzbihan, The Suluk al-Muluk, edited by M. Nizamuddin (Hayderabad: J.M. Printing Press, 1966), (hereafter cited as the Suluk), p. 5a. I have learned that a new edition of it by Muhammad Ali Movvahed has been published in Iran.

${ }^{8} \mathrm{Ibid}$. The translation of passages from this book is mine throughout.

${ }^{9} \mathrm{He}$ elaborates on the virtue of defining one's terms in any discussion of politics. See Ibid., p. $13 b$.

${ }^{10} \mathrm{Ibid}$., p. $15 \mathrm{a}$. 
as to defend the abode of Islam from the infidels and the rebels, 6) just, so as not to commit injustices, 7) mature, 8) sane, 9) a free man, 10) a male, 11) sound in hearing and sight, and 12) sound in speech..$^{11}$ He rejects the Shi'a qualifications of leadership by stating that it was not a condition that the leader should be infallible or that he should be a member of the Hashimite branch of Quraysh. He also quotes Abu-Hafs al-Nasafi's view that the leader has to be present and not in occultation. ${ }^{12} \mathrm{He}$ further adds that having all the afformentioned qualifications does not automatically translate into leadership. Only after people have paid homage (bayah) to him, would the qualified person be recognized as the leader.

The position of leadership, Fadl-Allah states, is contracted by one of the following four methods. The first method is the election of the leader (imäm) by the consensus (ijmā) of the Muslims and the homage of 'the people who loose and bind,' that is, the elites, the electors (ahl al-hall wa al- 'aqd), and those of the 'ulama, judges, the officials, and the leading persons (vujüh-emardom) who can be present. The second method relates to the nomination by the preceding leader (imäm) of someone with the necessary qualifications. Thus, if a less qualified person is nominated he will not be accepted. The third method of contracting the position of leadership (imamate) is the method of consultation. The leader (imaim) entrusts the issue of the election of the new leader to a council (shürā) of two or more so that a leader be appointed. ${ }^{13}$ The fourth method is taking the position of leadership by force. In Fadl-Allah's words:

The fourth method of contracting kingdom and imamate is through domination and military force. The culama have stated that when a leader (imām) dies and a person assumes the position of leadership (imamate) without the homage (of the people) and without anyone having made him caliph and he subdues them with his power and military force, his leadership is contracted, whether he is from the Quraysh or not, an Arab, Persian, or Turk... And since he has assumed the position of leadership through domination and power, he will be called the ruler (sultan). The titles imäm and caliph can also be applied to him. ${ }^{14}$

Certain observations are in order here. The first is that in describing the method of contracting the position of the leader (imām), Faḍl-Allah has simply

${ }^{11}$ Ibid., 15a-15b.

${ }^{12} \mathrm{Ibid}$., p. 15b This is in reference to the Shi'i view according to which leadership is the prerogative of the twelve infallibles from the household of the Prophet.

${ }^{13}$ Ibid., pp. 15b-16b.

${ }^{14}$ Ibid., p. 17a. 
presented the idealized version of the appointment or election of the first three caliphs. In other words, sanction for these methods is found respectively in the succession to Abū-Bakr (11-13/632-634), 'Umar (13-24/634-644), 'Uthman (24-36/644-665). The second point is that in describing the aforementioned methods, he has in mind the leader for Islamic society and reserves for this leader along the words imäm and imamate, i.e. leader and leadership respectively. As the above passage shows, in talking about the fourth method of contracting the position of leadership, he uses kingdom and leadership (padeshahi va imamate interchangeably or both with an "and" between them. ${ }^{15}$

There is no precedent for the fourth method in the early history of Islam. To borrow the late Sir Hamilton Gibb's characterization of classical Sunni political theory, it is "in fact, only the rationalization of the history of the community." 16 Fadll-Allah, is rationalizing and thereby legitimizing the new political order set by "Ubayd-Allah Khan. He imposes an additional condition, however, for the ruler. $\mathrm{He}$ is not permitted to act on his own will. He has to act within the bounds of the Islamic law, the shariah. "It is incumbent (upon the people)," writes Fadl-Allah "to obey the imäm/sultān's decisions whatever he commands or prohibits so long as they are not contrary to the Shariah (law), whether he is righteous ("ädil) or despotic (jäir)."'17 This takes Faḍl-Allah to the classic Islamic dilemma of the relationship between the ideal and the real. He has to strike a balance between the raison d'etat of the Islamic state, i.e., the implementation of the shariah, and the practical rule of the new king. The result is a mixed-bag of autocratic monarchy and the guardianship of the theologian jurisconsult, functioning in parallel. It is this dual characteristic that makes his political thought so intriguing. On one level, his state resembles the Safavid administration, while on another level his exposition of the role of the "ulama resembles the government of the theologian jurisconsults, who have been at work in Iran since the revolution (1977-79). ${ }^{18}$

A look at the structure of these parallel institutions clarifies the point. A king, a minister, governors, and tax collectors constitute the authcratic aspect

\footnotetext{
${ }^{15}$ Faḍl-Allah's explanation for using these two words interchangeably or jointly is as follows: "And if the king (sultan) of Islam, because of the lack of certain qualifications for the ideal leader (imam), is ruling through force, and he wants to be accepted (by the people), he should carry on the very duties which are incumbent upon the ideal ruler, the imam. This is the reason why in this work ...the word sultan is used interchangeably with the word imam." (p. 14b)

${ }^{16}$ See H.A.R. Gibb, Studies on the Civilization of Islam (Boston: Beacon Press, 1962), p. 162. ${ }^{17}$ See The Suluk, p. 17a.

${ }^{18}$ For the philosophical foundation of the political regime in Iran today see Ruhollah Khomeini, Islam and Revolution, translated by Hamid Algar (Berkeley: Mizan Press, 1981); and Farang Rajaee, Islamic Values and World View (Lanham, Md: the University Press of America, 1983), pp. 56-57, and the sources cited therein.
} 
of Faḍl-Allah's state, while a shaykh-al-Islam, the mujtahids,or muftis and the judges constitute the religious element as the political institution of the guardianship of the theologian jurisconsults. The king needs a minister to manage the affairs of the state. "In the shariah, Faḍl-Allah writes, "ministership means the deputyship of the king of the caliph."19 The basis of his appointment, according to Faḍl-Allah is provided in the Qur'an in the verse where Moses prays to Allah: "Appoint for me a minister (wazir) from my folk." (xx:29) ${ }^{20}$ Quoting Abu-al-Hassan al-Māwardi (d. 450/1058), Faḍl-Allah identifies two types of ministers: ${ }^{21}$

Ministers are of two kinds: deputy (tafividi) and agent (tanfizi). The deputed or entrusted ministership refers to the kings' appointment of someone whose authority extends to the implementation of all affairs... It is necessary that the deputed minister should possess all the qualifications of the imàm, save his lineage to the Qurayshi tribe. ${ }^{22}$

By deputed ministership, Fadl-Allah means total deputyship of the king. Similar to any strong prime minister in a modern parliamentarian regime, the wazir (minister) is delegated unlimited authority for managing the affairs of the state. The deputed minister, however, is not authorized to command the following three functions: 1) removal of the imām; 2) dismissal of those governors whom the king has appointed, and 3) endorsement of his own position to another person. ${ }^{23}$

The second kind of ministership, the representative one, is a position in which the minister is simply an agent or "envoy" between the king (padeshah) and the people as well as regional governors (waliyan). He is not required to possess all the qualifications of the imām, but he should be "trustworthy, male, and not greedy so that he may not be bribed." ${ }^{24}$ Below the position of ministership comes the position of the commander (amir). "In the parlance of the Islamic law (Shariah)," Fadḍl-Allah states, "the amir is the one who is appointed by the imäm/sultan in a province of Islamdom as the governor and ruler." ${ }^{25}$ Similar to the position of ministership, the post of amirshia is of two

${ }^{19}$ See The Suluk, p. 18a.

${ }^{20}$ In quoting the translations of the verses of the Qur'an I have used Marmaduke Pickthall,

The Glorious Qur'an. (Albany: SUNY, 1976) unless otherwise noted.

${ }^{21}$ See Abu-al-Hassan al-Mawardi, Al-Ahkam al-Sultaniya wa al-Wilayat al-Diniya (Cairo: Mustaf al-Babi al-Halabi, 1966), second chapter.

${ }^{22}$ See The Suluk, p. 182a.

${ }^{23}$ Ibid., p. $17 \mathrm{~b}$.

${ }^{24} I d$.

${ }^{25}$ Ibid., p. 19a. 
kinds, general (ämma) and specific (khässā). The general amir refers to the one whose mandate includes the affirs of a certain province, in toto, whereas the specific amir or commander refers to the one commissioned for a speciific duty, but only related to military affairs.

The specific commandership (amārat-e-khāssā) is when the commander is appointed for managing the special army, punishing the peasants, protecting the essence of Islam and driving away the enemies of Islam out of the Islamic territory. ${ }^{26}$

Faḍl-Allah explains in detail the process for the appointment of judges, mayors, police officers, and tax collectors to the smallest details. While those subjects may be related to my discussion indirectly, the treatment here is limited to the issues more directly related to the question of leadership and sovereignty.

How does the political apparatus relate to the parallel religious institutions of the 'ulamā, discussed earlier? The answer may be found in the duties of the king. According to Faḍl-Allah, ten duties are incumbent upon the leader because of his position as imäm/sultän. He should: 1) protect the religion in accordance with the principles established through the consensus of the forefathers of the community; 2) execute decrees among the people who have disagreements, and stop their animosity so that his justness may gain universal recognition; 3) protect the essence of Islam and drive its enemies away from its borders, so as to facilitate the Muslim's life; 4) implement criminal penalties ( $h u d \bar{u} d$ ) so that the sacrosancts of Allah may be well protected; 5) strengthen the frontiers of Islam and appoint strong persons over regions where infidels might enter the Islamic territory; 6) fight those who display enmity toward Islam, but only after they have been invited to accept Islam or, at least, strike peace with the Muslims; 7) collect revenue from the public lands $(\text { fay })^{27}$ and other taxes, particularly the one-fifth (khums) from booty; 8) fix the stipends of the needy without prodigality or parsimony; 9) demand accountability from those to whom he entrusts the affairs of the kingdom; and 10) personally oversee the affairs and enquire into the situation and conduct of others. ${ }^{28}$ As a whole, these duties may be summarized in the phrase alluded to earlier as Fadl-Allah's raison d'etat of the Islamic polity: the aim of the government or "state" is not but "establishing the law (Shariah) and protecting the territory of the nation." Since the king is not the ideal leader and cannot, on his own, both extract and implement the laws, he is in need of the guidance of the religious leaders. This warrants the existence of an elaborate

\footnotetext{
${ }^{26} \mathrm{Id}$.

${ }^{27}$ Fay' is one category of wealth or/and in Islamic jurisprudence which comes under the domain of the Islamic rulers. See S.M. Taleghani. Islam and Ownership, translated by Ahmad Jabbari and Farhang Rajaee (Lexington, Kentucky: Mazda Press, 1983), pp. 94-95.

${ }^{28}$ See The Suluk, pp. 19b-20a.
} 
organization of the religious leaders who guarantee that public policies are formulated and implemented in congruence with the principles of the law. Note the following passage:

The King must seek out the most learned of the "ulama on the science of the shariah in his kingdom. . . and entrust to him the essential affairs of Islam. ${ }^{29}$

If there is more than one person with such qualifications, however, the priority is given to the one who is known for his "piety (wara) and who is free from greed even if less knowledgeable than the other one. And if many are known for their trustworthiness the one with expertise in the customary law ( urf) should be selected. . . In case of many candidates with such qualifications, the one with courage, steadfastness, and kindness should be appointed. ${ }^{n_{30}}$

This office is the highest ranking in the religious institution and, "in the parlance of the contemporaries and the people of the time," the person occupying the post is known as the Shaykh-al-Islam. ${ }^{31}$ His power is unlimited and it embraces even the king's. One could argue that this in reality represents a reassertion of the power of the religious institution vis-a-vis the political. Note Faḍl-Allah's view of the Shaykh-al-Islam:

Any matters of interest to Islam, referred to the king by the Shaykhal-Islam, should be implemented without any delay. The king should enjoin the military and all officials and those in charge of the affairs of the kingdom to implement the decisions of the Shaykh-alIslam. . . Any delay in the execution should be firmly punished. ${ }^{32}$

Considering that the Shaykh-al-Islam is appointed by the king, what guarantees that the latter's decisions will be respected? In response to this, Faḍl-Allah states that once the Shaykh-al-Islam is appointed the king must free him from his courtship "because company and service of the kings destroy the prestige of the "ulama forever." ${ }^{33}$ But, because the king has to be in continuous contact with the Shaykh-al-Islam in order to be able to manage his country according to the shariah, "there should be a group of masters of the (Islamic) sciences in the king's retinue who inform him of the opinion and the legal ruling of the 'ulamā. They may be considered the mediators between the men of science, including the religious law, and the king. They are called

${ }^{29} \mathrm{Ibid}$., pp. 21b-22a.

${ }^{30} \mathrm{Ibid}$., p. 22a.

${ }^{31}$ This is an interesting observation on Faḍl-Allah's part because at each epoch of Islamic history one or more particular title(s) enjoy(s) a high stature. Today for example, the title of "Imam" among the Sunni 'ulama and the title of "Ayat-Allah" among the Shi'i scholars are considered important.

${ }^{32}$ See The Suluk, p. 22a.

${ }^{33}$ Ibid. 
the heads (sadr)." ${ }^{34}$

Following the position of the Shaykh-al-Islam comes the position of the mujtahids or those who can issue legal rulings (mufit). Faḍl-Allah discusses at some length the meaning of independent reasoning (ijtihäd) and the qualifications of the mufti. ${ }^{35}$ In his view, had the imäm/sultän prossessed the required qualifications for practicing independent reasoning (ijtahid), there would be little need for the mujtahid or the mufti. So the king has no choice but to obey those "who present answers to current issues based on the derivative ordinances of the science of the sacred law (the shariah). ${ }^{36}$ One last related point is that the Shaykh-al-Islam, the șadrs and the muftis should be sufficiently paid, from the state treasury, so that they may not be susceptible to bribery.

Other offices following the muftis are the offices of the judges ( $q \bar{a} \bar{d} \bar{i})$ and the enjoiners of the good and the prohibiters of evil (muhtasib), or the enforcers of Islamic public morality. Faḍl-Allah in detail discusses their functions, qualifications, and the manner in which they are appointed. These are beyond the scope of this discussion, but suffice it to say that the religious institutions continue to function alongside the political institutions with almost as elaborate a governing apparatus. The king is the actual and absolute sovereign above and beyond all else, and yet, at the same time, he is bound by the decisions of the Shaykh-al-Islam, whom he himself has appointed. A ray of optimism and idealism runs through this interesting scheme. Faḍl-Allah puts his full trust in the optimistic Islamic view of man that once a believer, a Muslim would become a loyal observer of the shariah, whether he is in the position of an absolute king or an all-powerful Shaykh-al-Islam.

Faḍl-Allah's theory of government, however idealistic, is very important. On the one hand, it is another manifestation of the juridical trend in Islamic political thought insofar as it created a balance, although a precarious one, between the demands of the ideals of Islam and the actual life of the victorious Ubaydullah Khan Shaybani, in re-establishing the Uzbek kingdom. While upholding the ideal version of traditional Sunni political theory, Fadl-Allah was able to find some legitimate basis for the rule of the Shaybani Khan and thereby to encourage support for his political order. On the other hand, FaḍlAllah's theory later served as a model for the subsequent kingdoms and empires, including the Shi'i empire of the Safavid in Iran. Vocabularies such as Shaykh-al-Islam, sadr, muhtasib, padesha, wizir, and amir, discussed in detail by Faḍl-Allah, later became very common in the political literature of the Safavid court. Indeed the way in which the Safavid kings conducted their 
rule in the presence of an elaborate $S h \bar{i} \bar{i}$ religious hierarchy, in many respects, resembled the state envisaged by Faḍl-Allah. In other words, as argued earlier, the juridical trend in Islamic political thought displayed a remarkable continuity both in terms of time and place, with the persistence of two parallel concepts, one representing the ideal and the other the practice.

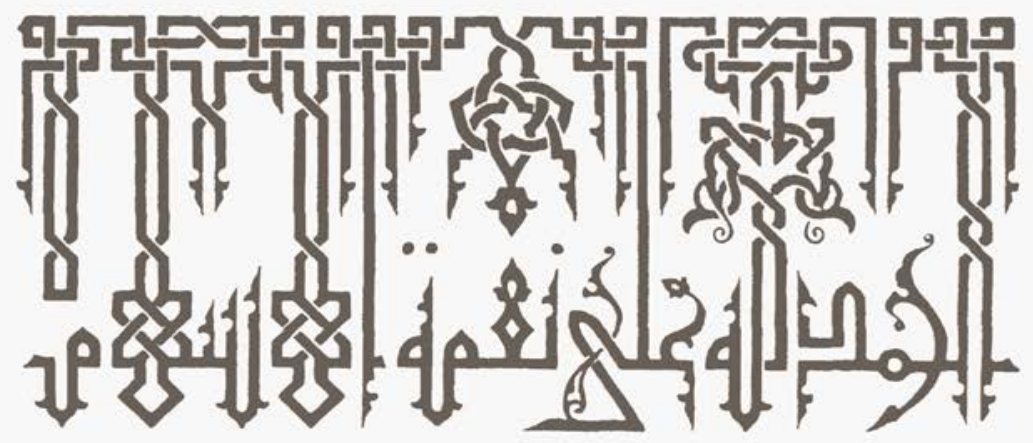

